\title{
$3 S$ 技术在水利工程地质勘测中的应用
}

\author{
周峰 \\ 东台市水利勘测设计室 \\ DOI:10.32629/hwr.v4i5.2963
}

[ 摘 要] 水利工程作为一项基础性建设与中国国计民生有着直接的关系,在这其中有一项重要的环节就是地质勘测, 对地质进行勘测时采用3 $\mathrm{s}$ 技术,勘测准确率提升的同时勘测效率也会有所提升, 以此将水利工程信息化建设得以实现。因此,本文对水利工程地质勘查中 $3 \mathrm{~s}$ 技术的应用进 行了阐述。

[关键词] 3S技术; 水利工程; 地质勘测 ; 应用

目前, 我国对于水利工程的建设十分的关注, 因此其是一项基础性 建设且与我国国计民生息息相关。水利工程中的地质勘查作为其建设 初期的主要工作, 有着十分重要的地位, 而3s技术的应用无论是对勘察 结果还是勘察效率, 都具有显著的效果, 对于建设水利工程以及其发展 有着很大的帮助。所以, 本文阐述 $3 \mathrm{~s}$ 技术在水利工程地质勘测中的具体 应用。

\section{1 简述 3s 技术}

$3 \mathrm{~s}$ 技术包括三项技术, 特别是全球定位系统, 遥感和地理信息系统。获 取点和平面上的空间变化和信息通常使用全球定位系统和遥感技术, 而地 理信息系统则用于存储, 分析和处理空间数据 ${ }^{[1]}$ 。

\section{2 分别说明在水利工程地质勘察中 $3 S$ 技术的应用}

$2.13 \mathrm{~s}$ 技术之全球定位系统

全球定位系统技术具有定位以及精密三维导航的功能, 且极具保密性 以及抗干扰性。全球定位系统技术是通过对卫星发射的信号进行接收, 同 时将接收到的数据进行处理, 将测量点的空间位置进行确认。在水利工程 地质勘察建设中全球定制系统应用极为广泛, 全球定位系统简称GPS, 可应 用于航测成图中的每一个阶段, 比如说机载全球定位系统航测、航测外业 控制测量、以及航拍飞行导航等, 对于各种形式的比例尺地形图的绘制, 可以利用测试控制点的添加, 运用全球定位系统实施动态定位技术进行, 在水利工程施工放样中将其充分利用。全球定位系统静态定位技术在水利 工程地质勘查中是最为普遍的应用, 它可应用与很多的方面, 比如说监测 地面沉降现象、监测大坝是否变形、测量隧道贯通情况、以及对水利工程 测控网高精度的布设等, 可以将实时监测以及控制水利工程中各种设施的 目的实现 ${ }^{[2]}$ 。随着中国不断的完善以及改进GPS控制网, 使得全球定位系统 技术的精准度不断的提高, 基于此, 水利工程无论是在设计方面还是在施 工质量方面都会有显著的提升。

\section{$2.23 \mathrm{~s}$ 技术之遥感}

遥感技术在收集信息时可不比直接接触现象或者目标, 而且有较高的 视点和探测范围、同时很快就能将信息获取且信息量极大、受限制条件很 少等。一般情况下, 可行性阶段或者是预可行性阶段应用遥感技术。将其 他的勘察手段与遥感技术协同使用, 对于地质测绘大范围的进行有很大的 帮助, 由于在野外进行地质勘察的时候会有不知道如何下手的情况, 而遥 感技术的应用可以将这种盲目性有效的减少, 以此将外业工作量很大程度 的减少, 不仅将选线选址的质量以及填图质量提高, 作业效率也很大程度 的提高了。最近几年, 在我国水利地质勘察中, 遥感技术作为地质勘查的一
种工程手段应用已经逐渐普遍, 在很多线状大型工程, 比如说距离较长、等 跨区域等进行调查, 主要位置有渠道预计输水隧洞等。同时也调查了很多 的地质现象, 比如说泥石流、崩塌以及滑坡等, 除此之外, 遥感技术的主要 用途还有调查熔岩以及工程地质调查以及制图等; 另外, 还对一些复杂特 殊地区的地质地形、水文、气候的等进行调查, 遥感技术在这些方面的应 用不仅省时间还很经济 ${ }^{[3]}$ 。

$2.33 \mathrm{~s}$ 技术之地理信息系统

对于水利工程中许多的地质图件, 比如说等值线图、柱状图、平面 图以及坡面图等, 运用地理信息系统技术就可将其自动绘制出来, 同时 还能够对许多的问题进行处理, 比如说空间数据的问题、相应属性数据 的数据库管理问题以及空间分析等 ${ }^{[4]}$ 。近年来, 地质勘查行业在制图输出 以及信息管理中致力于应用地理信息系统技术, 同时地理信息系统技术 也是地质勘察行业的发展趋势。对于城市防洪管理、洪涝灾害风险、还 有防洪评估等都已经越来越广泛的应用地理信息系统技术。对于可视化 表达的多种方式、水资源信息的交互式空间和属性查询、不同类型信息 的动态改变和空间分布过程的模拟、以及时空统计水资源信息等地理信 息系统技术的应用都能够方便的进行。除此之外，对于某地冲淤过程的 累积图、河道断面图的绘制、以及河道演变分析等也能够顺利的进行。 同时, 对于水下地形图数字化的各个不同的时期, 其数字高程模型都可 以分时期的建立。

\section{3 结束语}

$3 \mathrm{~s}$ 技术的应用随着科技的发展日趋广泛, 促进了各行业的发展。而目 前, 关系到国计民生的一项重要的工程就是水利工程, 同时它对经济的发 展也具有很大的影响。因为水利工程施工要勘察很多信息, 比如说环境、 水文以及地质等, 为了将其准确性以及效率保证, 3s 技术的应用就显得尤 为重要, $3 \mathrm{~s}$ 技术的应用能够使得水利工程更好地建设以及发展。

[参考文献]

[1] 徐显成. 35 技术在水利地质勘查中的应用 [J]. 水能经 济,2017,(05):230.

[2]何双剑,江丹,林顺海, 等.3S技术在水利工程土地勘测定界中的应用 [J].地理空间信息,2017,15(7):102-104.

[3]袁满,朱彦冰.遥感技术在水利工程地质勘测中的应用 [J].名城 绘,2019,(4):485.

[4]丁遵隆.3S技术在水利工程地质勘测中的应用 [J]. 城市地 理,2016,(3):178. 